\begin{tabular}{lll}
\hline 文 & 献 & 抄 \\
\hline
\end{tabular}

トリティカーレおよび親品種であるデューラム 小麦とライ麦の蛋白質合成

Dexter, J.E. and Dronzek, B. L.: Cereal Chem., 52, 577〜86 (1975).

6 倍体のトリティカーレと，この親品種であるデニー ラム小麦とライ麦の蛋白質合成について, 生育途中の種

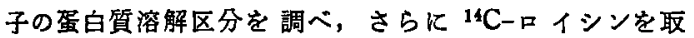
り込ませて検討を行なった。種子の蛋白質区分への ${ }^{14} \mathrm{C}-$ ロイシン取り这み量は, 開花後 2 週間で最大に達し, そ の後種子の生育に伴って減少した。蛋白質溶解区分への ${ }^{14} \mathrm{C}$-ロイシンの取り込み量は，3品種とも異なり特にて ルブミンとグリフジンに差異が認められた。トリティカ

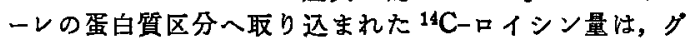
ルテニンを除いて他の区分は親品種の中間量であった。 また蛋白質の溶解区分の分布量も同様であった。トリテ イカーレのグルテニンは, 生育途中においてつねに親品

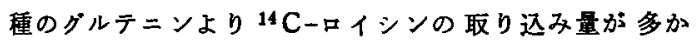
った。

（高野博幸）

\section{湿式加工およひ乾式粉砕による灌縮小麦蛋白質の 慁荿中における脂肪酸の変化}

Betschart, A.A., et al.: Cereal Chem., 52, 439 50 (1975).

乾式粉砕によってミルランから作った浱樎小麦蛋白質 (WPC) と，フルカリ溶夜を用いた加工によってミルラ ンから得た浱縮小麦蛋白質 (WAP-WPC) の脂肪酸組成 は，大教や小教の脂肪酸組成と類似していた。一般にリ ノレイン酸は 全脂肪酸含量の $50 \%$ あるいはそれ 以上あ り,一方オレイン酸, ペルミチン酸およびリノレニン酸は 各↔ 18.4〜25.0,20〜22.5 および 2.5〜3.9\%である。 $50^{\circ} \mathrm{C}$ に 12 週間貯蔵した時のWAP-WPC 酸沈でえ物 の脂肪酸組成は, WAP-WPC 加熱沈でん物の脂肪酸よ りも安定していた。貯蔵試料の揮発性成分について GC 分析を行ったところ，WPCにはnーへキサノールが， WAP-WPC 加熱沈でん物の 2 倍量含まれていた。しか し両者を混合し貯蔵した時には， $n$ 一へキサノールが極 めて少なかった。水分 $13 \% に し て 35^{\circ} \mathrm{C} に 24$ 週間貯蔵 した場合，WPC の脂肪酸はWAP-WPC 加熱沈でん物 の脂肪酸よりむ安定していた。この两者を混合した試 料は, $50^{\circ} \mathrm{C}$ に貯蔵するより $35^{\circ} \mathrm{C}$ 貯蔵の方が脂肪酸は安 定していた。

（高野博幸）

\section{小麦粉に及ぼす加熱温度と水分の影翌}

\section{1. 加熱加工法による小麦粉蛋白質の物理的・} \section{化学的変化}

Hansen, L. P., et al.: Cereal Chem., 52, 459 71 (1975).

熱交換機を用い加熱温度 $\left(108^{\circ} ， 150\right.$ および $\left.174^{\circ} \mathrm{C}\right)$, 水分 $(13 \sim 33 \%)$ および加熱時間（2，5および 10 分）
をいろいろ変え, 小麦粉 (1 等強力小麦利用) を加工し た。そして蛋白質の变化について，尿素中での溶解性， ゲルろ過，デスク電気泳動およびオミ，酸分析を行ない 検討した。この結果，低分子量蛋白質の集合体，フルブ ミンとグロブリンの消失, ベブタイドの開裂、リジン, フルギニンおよびシステンーシスティンの破壊が 認めら れた。これらの変化の主要原因は，加熱温度にあること がわかった。蛋白質の化学的一物理的変化としては，へ プタイド結合と S-S 結合の変化が認められた。

（宫野博幸）

\section{高水分含量トウモロコシの劣悪化}

Michael, E.M., et al.: Appl. Microbiol. 30, 103 9 (1975).

非密閉型の 2 基の小型サイロに正常な高水分含量のト ウモュコシ(HMC) を満たし, Helminthosporium maydis をくをなく接種した。中温菌, 乳酸菌, 腸内細菌, 酵母の菌数はトウモロコシを菌受容サンプルとして 220 日間の貯蔵期間を通して経時的に測定した。温度とガス 発生量む常時観察した。HMC が腐敗していく過程で乳

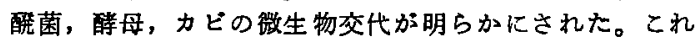
らの微生物交代は，前報の適正な条件下での正常な HMC の貯蔵中における結果だけでなく今回の実験でむ 遭遇したように微生物交代しうるということを基礎とし て, 前回の結果と比較検討された。H. maydis の多量 の接種は HMCの保存には顕著な効果はみられなかっ た。

（太田輝夫）

\section{甘味穀類加工品に添加したショ糖の固定化 インペルターゼ利用による自動測定法}

Finley, J.W. \& Olson, A.C.: Cereal Chem., 52, $500 \sim 505$ (1975).

甘味製品から抽出したショ糖の水溶性区分について比 色法で測定した。ろ過した抽出液を 2 等分し，一方をイ ンベルターゼを含むフェノールーフォルムフルデヒドの カラムに通し，他方はインベルターゼを含まない樹脂力 ラムに通した(ブランク)。そして還元䌅量をジニトロサ リチル酸比色法で測定した。ショ糖抽出後の全ての操作 は，テクニコンのオートナナライザーを用いて行なっ た。この方法を用い，大豆を含む小麦幣品およびトウモ ロコシー大豆一牛乳混合製品のショ糖量を測定した。

(高野博幸)

長鎖フェノール IV カシュウナッツ外皮液中の フェノール組成のオレフィン化合物の定量

TyMAN, J.H.P.: J. Chromatogr., 111, 277〜84 (1975).

薄層クロマトグラフィーとガスクロマトグラフィーを 併用することによって Anacardium occidentale から得 
たカシュウナッッ外皮液中の長鎖フェノール成分の不飽 和成分の定量に成功した。この方法は，天然あるいは工 業的に加熱またはデカルボキシル化したものに適用でき る。

(山下市二)

$$
\text { 長鎮フェノール } \mathbf{V} \text { カシュウナッツ外皮液の }
$$
ガスクロによる分析

TyMAN, J.H.P.: J. Chromatogr., 111, 285〜92 (1975).

天然産あるいは工業的にデカルボキシル化して得たカ シニウナット外皮液 (CNSL) 它ガスクロマトグラフィ 一で分析した。この方法で要求されるのは，比較的非極 性の充てん削を高温で使用すること，テーリングを避け るためには，不飽和成分を水素添加して飽和し，揮発性 メチルェステルの形にする必要がある。（山下市二）

\section{リンゴの熟度の調節Ｉ落果および收穫時期別 果実品質への生育調節绪の影響}

Looney, N.E.: I. Amer. Soc. Hort. Sci. 100, 330 32 (1975).

リンゴ (McIntosh 種)にエセホン(正常な収檴に先立 って 3 週間前に $600 \mathrm{ppm}$ ，また 1 週間前に $300 \mathrm{ppm}$ を 使用)と NAA ( $\alpha$ ーナフタレン酶酸)または $10,20 \mathrm{ppm}$ の 2,4，5-TP ( $\alpha$-トリクロロフエノキシプロピオン酸) を組合わせて用いた場合，赤味色が増し，それぞれの処 理後 6 ないし 12 日で収穫された果実の硬さは隇少した。 NAA あるいは 2，4，5-TP は落果を十分阻止得ない。

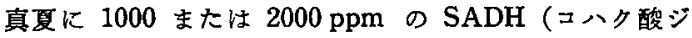
メチルヒドラジッド)好理すると，色と硬さが改良され， エセホンーオーキシンでの処理で落果比率は著しく減少 する。

(片山 脩)

\section{リンゴの熟度の調節ＩI 果実の熟度, 貯战状態,} 日持ちなどに対する生㕕調節剤の効果

Looney, N. E.: J. Amer. Soc. Hort. Sci. 100, $332 \sim 36$ (1975).

経時的に収穫したマキントシニ種リンゴの果実では品 質測定や官能審査から，かなりの幅が示された。20员で 熟成はエセホンーオーキシンで促進され $\mathrm{SADH}, \mathrm{CO}_{2}$ に よって遅らされる。 $0^{\circ} \mathrm{C}$ における果肉の軟化と酸の变化 の速度は，これら生育調節绪処理によって変わらない。 $\mathrm{SADH}$ は土チレンの生成を抑え, $\mathrm{CO}_{2}$ はエチレンの生 成と $20^{\circ} \mathrm{C}$ 亿果実を保ったときの軟化を抑制する。これ らの効果は泠蔵されない果実に対して非常に大で， $0^{\circ} \mathrm{C}$ で30，60，90日保持した果実では直線的に効果が低下 する。SDAH と $\mathrm{CO}_{2}$ のいずれも $20^{\circ} \mathrm{C}$ での酸の損失に は影望しない。

(片山侢)

\section{リンゴ果実の老化崩かい程度とカルシウム㳍度との 関係}

Mason, J.L., et al.: J. Amer. Soc. Hort. Sci., 100, 343 46 (1975).

2 年間にわたって得たリンゴ (Spartan 種) 果実試料 において，その崩かい（breakdown）程度と果肉中の
$\mathrm{Ca}$ 溇度は密接な関係を示した。 $\log \mathrm{Ca}$ と崩かい直線 または $\log \mathrm{Ca}$ と $\log$ 崩かい度の関係を用いて 0.9 と いう相関係数を得た。2つの式で計算した崩かい程度は Ca 70 ppm で $100 \%, 100$ ppm で 46 100\%, 150ppm で 3〜12\%，200 ppm では 2\% 以下である。

（片山俏）

\section{マンダリン砂じょうの長鎖，飽和， 不能和崖化水素}

NoRdBY, E. H. and NaGY, S.: Phytochemistry, 14, (8), 1777 82 (1975).

5 種のマンダリン (Mediterranean, Honey, Wilking, Kinnow, King) の砂じうの長鎖飽和，不飽和炭化水 素含量を測定した。直鎖状のものが飽和炭化水素の $47 \%$ 以上, モノエン宸化水素の $75 \%$ 点める。䬲和区分の 主要化水素は $n-C_{25}$ であるが，モノエン区分では Kinnow, King では $n-C_{25}$ が, Mediterranean, Honey, Wilking では $\mathrm{C}_{29}$ が多い。5種はその炭化水素パター ンでそれでれ区別でき，他の柑㹉類からも区別できる。 飽和 $\mathrm{C}_{23}, \mathrm{C}_{25}$ 炭化水素のノルマル/イソの比が非常に大 きいことがマンダリン種 Citrus unshiu, C. reticulata の特徵であるととを以前に示したが，C. nobilis， C. deliciosaでもそれが見出された。（細田 浩）

\section{トウモロコシを加えたフィードロットウェイスト} での酸酵中における菌相の变化

Hrubant, G.R.: Appl. Microbiol., 30 (1) $113 \sim 19$ (1975).

粗粉砕したトウモロコシとフィードロットウェイスト をろ過した液を $2: 1$ に混ぜて調製されたものを基質と した酸醉をこの新しいブロセスは含んでいる。このサイ レージよう瞪醳の菌相変化を謂べたところ, 当初せいぜ い $1 \%$ 程度であった乳酸菌が優占的になった。乳酸菌の ピークは $2 \times 10^{9} / \mathrm{g}$ となり酸醉中最後まで一定である。 当初存在するコリフォーム型の菌とか Trichosporon cutaneum Otaなどは生産された酸により殺される。酰 醉は 2 相にわけられる。すなわち初めの 24 時間は一テ 口乳酸菌が全微生物中の $90 \%$, 乳酸菌中の $95 \%$ 達す る。後半はホモ拜酸菌が堌加し，6日目にはストレブト バクテリウムとサーモバクテリウムとベーターパクテリ ウムの3種の混合となる。一方酵母はキーンディダ采々 ビキフ系の 2 種類になる。とのような微生物の連鎖の知

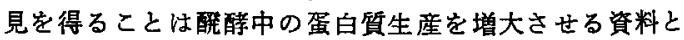
なるむのである。

（柳本正勝）

\section{牛乳中のたんぱく質定量のための Pro-Milk 方法の共同試験}

Sherbon, J.W.: J. Assoc. Offic. Anal. Chemists, 58, (4), 770 80 (1975).

7 つの牛乳試料と 2 つ標準色素液について，6力所 の共同研究室で Pro-Milk法によるたんぱく質含量の分 析を行なった。非常に精度がよいために研究室間の偏差 は，かなり小さかったが，有意差を示した。未知試料 (2 組)も，他のものとの螘いが認められなかった。比色 
計のみによる希釈色素液のテストは, 各研究室間に偏差 を示したが，それは，それぞれの機械について注意梁く 補正する必要があるととを示していた。牛乳と色素夜の 試験で得られた偏差値の幅は，公定法として Pro-Milk 法が探用できるほど小さかった。（堤 忠一）

\section{均質牛乳と不均質牛乳中の脂質の定量のミルコー} テスター法の共同研究

Shipe, W.F. and SenYk, G.F.: J. Assoc. Offic. Anal. Chemists, 58, (3), 572 75 (1975).

マーク III工業用ミルコーテスターは, 不均質牛乳と均 質牛乳の両方のテストの結果, その信頼性の価値が認め られた。6つの研究公が，2つの試験に参加した。最初 の試験では, 研究空間の範囲は均質牛乳で $0.29 \%$, そし

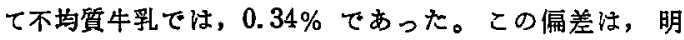
らかに不正確な目盛定めのためである。2 度目の試験で

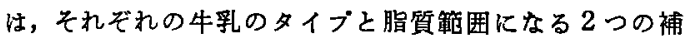
正用標準を用いた。その結果，偏差の範囲は，均質牛乳 て $0.04 \%$ ，そして不均質牛乳で $0.05 \%$ にっった。不均 質牛乳と均質牛乳の標準偏差は，それぞれ第 1 回目の試 駼で 0.008 および $0.010,2$ 回目は，0.005および 0.005 であった。原乳，不均質牛乳中の脂質定量のため の公定法の自動化法 I は，マーク III 工業用ミルコーテス ターの使用により均質牛秏中の脂質定量にも適用できる ようになった。

(堤 忠一)

植物糖脂質およびそれらの脱アシル化とメタノリシス 生成物のガス-液体クロマトグラフィー

Williams, J.P., et al.: Anal. Biochem., 66, (1), $110 \sim 22$ (1975).

モノガラクトシル ジグリセライド (MGDG) とジガ ラクトシル ジグリセライド (DGDG) とそれらの脱フ シル化とメタノリシス生成物の GLC 分析を行なった。 MGDG と DGDG, それらのガラクトシルモノグリセラ イドは,それらのトリメチルシリル誘導体としてクロマ トを行なった。ガラクトシルモとグリセライドは， Grignard 試薬とすい葴りパーゼとによってジグリセリ ドの局部的脱フシル化によって成生した。全脱てシル 化，モノーヒジガラクトシルグリセロールの生成物は， 0ーメチル, Oーフセチル，0ートリメチルシリルと，0ートリ フロロフセチル誘導体として分離された。MGDG と DGDG とメチル化ガラクトシル グリセロールのメタ ノリシス生成物の誘導体の GLC 分析は, 两脂質のガラ クトースとグリセロールおよび DGDG の 2 つのガラク トースの分離と定量的回収が認められた。（堤 忠一）

\section{二次元薄層クロマトグラフィーによる メチルヌクレオサイドの分離}

Munns, T. W. and Sims, H. F.: J. Chromatog., 111, 403 8 (1975).

RNA 中のメチルヌクレオシドを薄層クロマトグラフ ィーで分離するための展開溶媒と吸着绪の検討を行っ た。吸着戍として結晶セルロース $60 \%$ とシリカゲル 40 \%の混合物を用いて,二次元の展開を行うことにより 17 のメチルヌクレオシドを分離できた。分離可能なものの 中にはてデノシン，グフノシン，シチジン，クリジンの

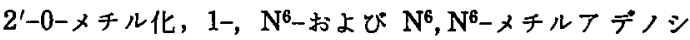

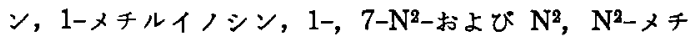
ルグフノシン，3-，4- および 5-メチルシチジンおよび 3- および5-メチルウリジンあ含まれている。これらは 各々の対応するメチル化されていないヌクレオシドおよ び塩基とす分離可能であった。

（田島 真）

\section{水銀の冷蒸気法による原子営光測定の改良}

Thompson, K. C. and Godden, R. G.: Analyst, 100, 544 48 (1975).

冷蒸気水銀蛍光検出に比較的简単な改良を加えること で，大幅に感度を增加させ，測定に要する時間を減少さ せることができた。0.02 ng の $2 \sigma$ (シグマ) 検出限界が 達成できた。

(安井明美)

\section{原子吸光分光計による魚肉組織中の水銀の迅速定量}

Teeny, F. M.: J. Agric. Food Chem., 23, (4), $668 \sim 70$ (1975).

原子吸光分光計による魚肉組織中の水銀の簡易，迅速 定量法について述べた。試料の分解は, 硫酸一硝酸一塩酸 により行なった。元素の状態に变えてフレームレス原子 吸光分光計で 定量するために, 15 分の分解時間で十分 に水銀を無譏態に变えられた。魚肉中の水銀の定量にお いて，この方法の結果と FDAの公定法を使用して得ら れた結果とよく一致した。

（堤 忠一）

\section{冷蒸気原子吸光法による種子, 穀粒, および食品中 の水銀のサブミクログラム単位の定量}

Dassani, S. D., et al.: J. Agric. Food Chem., 23, (4), 671 73 (1975).

種子, 琼粒，果物，野菜，魚および肉のような数種の 生物的試料中の全水銀の定量のために泠蒸気原子吸光法 を用いた。生物的試料は，濃硫硝酸で分解を行なった。 有機態の試料水銀は，三角フラスコを用い，硫硝酸によ り， $60^{\circ} \mathrm{C}$ で 5 時間分解を行ない 2 価イオンに变元 る。試料分解液は，その後，塩化第一スズで還元し，再 循環冷蒸気原子吸光法により，0.01 $\mu \mathrm{g}$ 以下で定量す る。水銀の最大量 9.45 と $7.15 \mathrm{ppm}$ 方温室トマト種子 と処理小麦粒にそれぞれ認められた。（堤 忠一） 